\title{
Between conquest and independence: Real wages and demographic change in Spanish America, 1530-1820
}

\author{
Leticia Arroyo Abad ${ }^{\mathrm{a}}$, Elwyn Davies ${ }^{\mathrm{b}}$, Jan Luiten van Zanden ${ }^{\mathrm{b}, *}$ \\ a Middlebury College, United States \\ b Utrecht University, The Netherlands
}

\section{A R T I C L E I N F O}

\section{Article history:}

Received 18 January 2011

\section{Keywords:}

Real wages

Living standards

Latin America

Early modern period

\begin{abstract}
A B S T R A C T
On the basis of a newly constructed dataset, this paper presents long-term series of the price levels, nominal wages, and real wages in Spanish Latin America - more specifically in Mexico, Peru, Bolivia, Colombia, Chile, and Argentina - between ca. 1530 and ca. 1820. It synthesizes the work of scholars who have collected and published data on individual cities and periods, and presents comparable indices of real wages and prices in the colonial period that give a reasonable guide to trends in the long run. We show that nominal wages and prices were on average much higher than in Western Europe or in Asia, a reflection of the low value of silver that must have had consequences for competitiveness of the Latin American economies. Labour scarcity was the second salient feature of Spanish Latin America and resulted in real wages much above subsistence and in some cases (Mexico, Bolivia, Argentina) comparable to levels in Northwestern Europe. For Mexico, this was caused by the dramatic decline of the population after the Conquest. For Bolivia, the driving force was the boom in silver mining in Potosi that created a huge demand for labour. In the case of Argentina, low population density was a pre-colonial feature. Perhaps due to a different pattern of depopulation, the real wages of other regions (Peru, Colombia and Chile) were much lower, and only increased above subsistence during the first half of the 18 th century. These results are consistent with independent evidence on biological standards of living and with estimates of GDP per capita at the beginning of the 19 th century.
\end{abstract}

(C) 2011 Elsevier Inc. All rights reserved.

\section{Introduction}

This paper presents series of long-term evolution of price levels, nominal wages, and real wages in Spanish Latin America more specifically in Mexico, Peru, Bolivia, Chile, Colombia, and Argentina - between ca. 1530 and ca. 1820 . These new series allow us to compare price and wage developments in Spanish Latin America with those in Europe in the early modern period. One of the key questions is the relative standard of living of the Latin American population in the centuries before the 19th century 'Great Divergence'. The sources used provide useful, although imperfect, information to assess the state of colonial Latin American living standards. To make our results comparable with those of the rest of the world, we have used the methodology developed by Allen (2001) and Allen et al. (2011) to estimate standardized real wages expressed as 'welfare ratios'. These welfare ratios measure the purchasing power of nominal wages in terms of a standardized basket of consumption goods, necessary for subsistence (known as the 'bare-bones basket'). The value of this basket is then compared with a similar basket in Western Europe while the real wage is expressed as the number of bare-bones baskets a family of four could afford with the wage of an unskilled labourer. Using this standard methodology enables us to link developments in wages and prices in Latin America with those of the rest of the world.

\footnotetext{
* Corresponding author.

E-mail addresses: larroyoabad@middlebury.edu (L. Arroyo Abad), elwyn@davies.nl (E. Davies), jvz@iisg.nl (J.L. van Zanden).
} 
We focus on the long-term changes in the levels of prices and wages between the Conquest in the 1520s and 1530s and Independence in the 1810s and 1820s. Measuring real wages (as 'welfare ratios') for Latin America is the aim of this paper, but this also allows us to answer a number of related questions. How expensive was life in the Viceroyalties of New Spain and Peru in these three centuries? How did real wages react to the severe decline of the population during the 16th and early 17 th centuries and to the partial recovery during the 18th century? Did real wages reflect these changes in the relative scarcity of labour, or did various forms of labour coercion keep them at an artificially low level? And how did real wages in Spanish Latin America compare with those in Western Europe?

We confirm the fact that living in colonial Latin America was costly. Prices were high throughout the region when compared to Europe. However, nominal wages were also high. As the region was the world's most important producer of silver, and wages and prices were measured in terms of that commodity, this result is not surprising; silver was relatively cheap there. This effect was stronger for the Potosi region; seat of one the main silver mines in the Americas.

Our main findings are that real wages in Mexico (and probably elsewhere) reacted to the sharp decline of the population after the Conquest in a way rather similar to patterns found in Western Europe (for example England and Tuscany) after the Black Death of 1348 . That is, real wages escalated in the very long run and reached levels well-above subsistence until the 18 th century. It was then that population recovery started driving real wages down to subsistence levels in Mexico around 1800 . The real wages upward trend was rather slow compared with Western Europe. The real wages were initially low due to the early stages of development of the labour market and the forms of labour coercion established by the Spaniards. In the Andes region (Peru, Colombia, and Chile) we do not find equally high real wages, and the rise above subsistence occurs later in the period suggesting continued labour scarcity during 18th century. In Potosi (Bolivia), the main silver mining centre in South America, wages were high, in particular for free labourers. However, a sizable share of the labour force was drafted from distant provinces. Finally, for the end of our period, the real wages for Argentina show a very high but declining welfare ratio. Our results are by and large consistent with biological standards of living studies and confirmed by tentative estimates of GDP per capita at the beginning of the nineteenth century. However, our data are in disagreement with Maddison's (2001) earlier GDP estimations for the 1500-1800 period, suggesting we should reconsider the overall economic growth experience of early colonial Latin America.

\section{The context}

Explaining the origins of Latin America's underdevelopment has been a popular topic. From structural and dependency theories to hypotheses about institutional persistence, scores of articles search for "the" explanatory factor that widened the gap between the region and the developed world. ${ }^{1}$ They all argue however, in one form or another, that underdevelopment had its roots in the colonial period. To test those ideas, it is therefore pertinent to understand the performance of the colonial economy and compare it internationally. Thanks to numerous scholars, we have rough estimations of the growth performance of selected Latin American countries from the early 19th century onwards (see the overview in Prados de la Escosura, 2009). Yet, we lack a macro perspective of the living standards during colonial times (16th-18th century), which could offer a basis for a comparative analysis of Latin America's economic performance in the colonial period. An integral reconstruction of the national accounts of the region is probably not feasible, but we can estimate the development of real wages in a systematic way, making it possible to compare with real wage trends in the rest of the world.

Research on Latin American prices and wages has been relative scarce compared with other regions, in particular Europe. Despite several studies on the topic, there was no consistent framework and no clear overview of the long-term trends in the development of wages and prices in Spanish America in this period. Scholars have repeatedly noted this void in the literature. Blanco and Romero Sotelo (2000) in their work on economic history of Mexico observe that inflation trajectory is still unknown with the data available. ${ }^{2}$ In the Oxford Handbook of Latin American History (2011), Coastworth and Summerhil (2011) note that the price history of early colonial Latin America is virtually nonexistent. They underline its relevance for fiscal accounts, agricultural production, mining, and living standards. Following the footsteps of research on other regions, we present a unified and coherent picture of real wages of five countries in the region: Argentina, Bolivia, Chile, Mexico, and Peru. ${ }^{3}$

The European encounter with the 'New World' involved the contact with and transformation of very diverse populations: from sophisticated civilizations to nomadic tribes. In the name of the crown and god, Europeans explored and settled this new continent changing the course of their native people forever. This vast extension of land was initially divided in two viceroyalties: New Spain (Mexico and Central America) and Peru (South America). ${ }^{4}$ Yet, the Europeans mainly concentrated their efforts in areas of sedentary indigenous settlement. Central Mexico and the central Andes became the pillars of Hispanic Latin America. ${ }^{5}$ The fringes of the Spanish empire in Latin America consisted of colonies of difficult access, distant, or of less value to the colonial enterprise (such as modern Argentina, Uruguay, and Chile).

This distinction between the central areas and fringes of Spanish domination is consequential in explaining the nature of the colonial operations. In the central areas, the Spaniards settled to secure the (initially) abundant indigenous labour base necessary

\footnotetext{
${ }^{1}$ A thorough discussion of all these theories is beyond the scope of this paper. Raul Prebisch is known as the creator of the structuralist theory and Celso Furtado (1976) is one of main voices behind dependency theory. Engerman and Sokoloff (1997), Acemoglu, Johnson, and Robinson (2001) claim that colonial institutional persistence deeply influences current economic outcomes.

2 Blanco and Romero Sotelo (2000), p. 52.

3 For Europe, see van Zanden (1999) and Allen (2001); for China, see Allen et al. (2011); for the Ottoman Empire, see Özmucur and Pamuk (2002).

4 This political division changed over time leading to more viceroyalties.

5 See Lockhardt and Schwartz (1983) for a full discussion of types of indigenous settlements in pre-Columbian Latin America.
} 
to gain access to precious metals. Moreover, the Spaniards took full advantage of the more advanced structures of these societies including political organization, agricultural technology, and tribute systems. These areas became the basis for colonial growth in Hispanic Latin America. The increase in labour demand in silver mining was solved by a compulsory draft. The silver centres became central nodes in the developing market economy of the region. For example, given the limited imports from Spain in Peru, neighbouring regions supplied other goods. The structure of colonial activities created poles of development that pulled in resources from other locales, creating a more integrated economy (Assadourian, 1982).

In areas with nomadic or semi sedentary native population, the Spaniards founded their own centres for administrative purposes. Santiago de Chile and Buenos Aires are examples of such practice (Hidalgo, 1984). The settlement in the southern cone (Argentina, southern Brazil, Paraguay, and Uruguay) was the product of failed search of precious metals. Indigenous populations almost disappeared there, and population densities were very low. In modern Venezuela, the Spanish colonization was mostly restricted to Caracas supplying cacao to the empire. In the frontier of the fringes, the presence served to secure the Spanish possessions from foreign powers (Lockhardt and Schwartz, 1983).

All regions shared, however, a common experience with the encounter with the Europeans. Lack of immunity to diseases carried by Europeans and Africans, lead to the rapid spread of various diseases with devastating effects on the indigenous population. Violence, disease, and social disruption are quoted as the salient determinants of the largest loss of human lives in history. However, the scale of the overall depopulation is less certain. The degree and timing of the decline varied significantly in the region depending on the geographic distribution. Figures range from $90 \%$ to $20 \%$ of the total population before the encounter. ${ }^{6}$ By comparison, the Black Plague of 1348 'only' killed about one-third to one-half of the population (Livi Bacci, 2008).

For Mexico, the "High Counters" calculate a depopulation of over $90 \%$ while revisionists claim a lower-bound estimate of $20 \%-$ $50 \%$ (McCaa, 1995, 2000). ${ }^{7}$ In the viceroyalty of Peru, disease might have preceded the arrival of the Europeans. To the usual epidemics, the demographic decline was compounded by the Inca war of succession between Huascar and Atahualpa. Assadourian (1989) and Shea (1992) argue that the 16th century decline in the Andes was probably less dramatic than in Mexico, but the literature is yet inconclusive. Demographic recovery, which began in the 17th century in Mexico, may have come later to Peru due to the influenza epidemic of the 1720s. What is common between these two regions is a severe decline after European contact followed by a recovery interrupted by periodic epidemics. The depopulation phenomenon in the fringes is not as well researched; however, scattered evidence also suggests population decline in the first century of European contact (Newson, 1985). The urban centres in Chile experienced great expansion from 1700 until the early 19th century. The population tripled, starting from a very low base during early colonial rule (Carmagnani, 1967). In the La Plata basin, the encounter with Europeans translated into constant efforts to subdue the indigenous populations.

The dramatic decline of the indigenous population is one of the key features of Latin American development in this period that deeply influenced the labour market. Securing labour was of utmost importance and the Spaniards introduced new and adapted existing forms of labour coercion to meet their needs. ${ }^{8}$ The institutions of forced labour developed in Spanish Latin America from pre-existing institutions in the Old and the New World. In Aztec and the Inca empires, institutions of coerced labour played a predominant role in economic life, producing a large share of the goods needed for the elite. The origin of the encomienda can be traced to the Antilles ca. 1495 under the names of encomienda and repartimiento. Both were royal grants of the right to demand indigenous peoples tribute and labour, assigned to individual Spaniards (Zavala, 1935; Romano, 2004). Granting an encomienda was a standard way for remunerating the first generation of conquistadores for the role in the conquest. Moreover, given the absence of wage labour in the New World, it was initially the mechanism to obtain labour from the indigenous populations. Various forms of such institutions spread rapidly in New Spain and Peru, and proved essential to the functioning of agricultural and mining enterprises.

While encomenderos pressed for the expansion of these institutions of coercion, the crown preferred to create a free labour force. Depopulation and complaints from non-encomenderos resulted in a decline of the number of natives participating in the encomienda system. A royal reform dated from 1601 terminated this system for all sectors except mining. De facto, the practice prevailed until the early 1630s, after which it was still only relevant for a few special niches in the economy (Gibson, 1964; Zavala, 1935). In Mexico, the total number of existing encomiendas dwindled from a high of 537 in 1550 to 126 in 1560 (Zavala, 1935). In Peru and Bolivia, forced labour used in mining became known as the mita (the same term the Incas had used for drafted labour). The rise of this system was in response to the huge increase of silver mining in Potosi but gradually it became less important (Bakewell, 1984; Puente Brunke, 1992). Under the mita, one-seventh of the adult male Indian population was drafted on a rotating schedule. The Spanish authorities soon realized the inefficiency of these ways of extracting labour, and already from 1603 onwards a movement started to abolish, or at least to reform and to streamline, these systems. ${ }^{9}$

Recent research on this topic suggests that the widespread presence of forced labour has been exaggerated. Scholars have long looked at the Peruvian mita as the quintessential example of the use and abuse of indigenous forced labour for silver extraction. However, over half to 70\% of the labour force in the mines in Peru and Mexico was free labour (Bakewell, 1984; Tandeter, 1993). In addition, the free and forced categories were not immutable. Drafted labour in Peru could buy its freedom from the mita

\footnotetext{
${ }^{6}$ For a discussion on the calculations, see Livi Bacci (2008), Dobyns (1963), Malvido (2006), and Newson (2006).

Among the "High Counters", Cook and Borah are the most famous. Among the revisionists, the "minimalists" such as Rosenblat, see a much smaller magnitude of roughly $24 \%$.

${ }^{8}$ The Spanish crown chose to consider Indians as free people, marking a distinction with slavery and feudal tenure. This move marked the beginning of the tension between the colonial need of labour versus the humanitarian treatment of the new subjects (Newson, 1985).

${ }^{9}$ In the 16th century, there was an ongoing discussion between colonial officials, representatives of the Catholic Church (who were often opposed to it), and the central state in Spain about their legitimacy and functioning (Simpson, 1966).
} 
service. In New Spain, mining activities were carried out solely by free labour in the north while weakly relying on encomienda labour in the center and south. The degree of coercion was also linked to the labour market institutions of indigenous population involved. In Peru and southern and central Mexico, the indigenous communities were used to draft work; however, in northern Mexico, the Indians were mostly nomadic and not used to working for the state (Bakewell, 1984).

One can even argue that the main innovation introduced by the Spanish conquerors was not so much labour coercion, but a labour market with paid wage labour. This new institution took time to fully develop and labour coercion remained important until the early 17th century (in Mexico) or even later (in Peru). Moreover, forced labour was not wage-free. As stipulated by the many laws on the forced labour system, labourers were entitled to compensation for their services. Even in the allegedly most injurious mita, wages were regularly paid in cash, and workers were only set to work during part of the years. The workers could then sell their labour at a higher free market wages during half or one third of their stay. In addition, they were sometimes compensated for travel times and other costs (Bakewell, 1984). In New Spain, miners were free agents working voluntarily (Brading, 1971). In the Guadalajara region in Mexico, free rural labour accounted for the bulk of the supply in the 17th century (Van Young, 1981). In Chile, the boom of the mining sector required more labour force than the encomienda could provide. As a result mestizos and free Indians migrated to the northern region lured by high wages (Carmagnani, 1963). From the reforms of the early 17th century onwards, free wage labour became the norm in large parts of Latin America, but it was often mixed with elements of coercion. The term peonage has been introduced to describe this: quite often labourers were bonded by the credit they owed from their employer, the hacendados or the owner of a mine. The degree of debt bondage varied from region to region and from period to period, but this continued to play a role well into the 19 th and even the early 20 th century. ${ }^{10}$ Wage labour was obviously embedded is the very unequal socio-political relationships of the period, but that was of course the case elsewhere as well (see for example the English case: Steinfeld, 1991).

To sum up, in the different parts of Latin America wage labour became a common phenomenon and wage income emerged as an important source of income for the indigenous population. Coercion continued to play a role, however, implying that we have to be careful in interpreting the wage (and price) data, taking into account the institutional setting of the labour market. Yet at the same time, the widespread use of wage labour means that we can use information on wages and prices as a first approximation of trends in living standards and labour productivity in the long run.

\section{The data}

To compare real wages trends in these various regions within Latin America and with the rest of the world economy, we have applied the systematic framework for measuring real wages developed by Allen (2001) and Allen et al. (2011). It consists of three steps: 1. To measure the annual wage income of an unskilled labourer (preferably in the building industry); 2 . To estimate the value of a 'barebones' basket of subsistence goods required for survival of a family of 4 (two adults, two children) and 3 . To calculate the ratio between 1. and 2., the 'welfare ratio', which is the number of baskets that can be bought with the wage of the unskilled labourer.

In Allen, 2001, the relative living standard of unskilled labourers in Europe between 1300 and 1914 was calculated using a standardized consumption basket of goods taken from Strasburg around 1750. Initial attempts to construct similar baskets for Asian countries such as China, Japan, and India revealed that the European basket was much too luxurious for that purpose. In fact, a more basic basket of consumption goods was a better basis for inter-continental comparison. This very basic basket was called the 'bare-bones basket', contrasting with the 'respectable basket' that had been used initially for intra-European comparisons. Its core consists of the cheapest staple food - sorghum in China and oats (used in porridge) in Europe - that supplies most of the calories needed for survival. In addition, small amounts of meat or fish, and butter or oil, are also included so that the total basket supplies about 1.940 calories per day (the standard of all barebones baskets). Finally, small amounts of textiles, soap, firewood (or coal/peat), candles, and lamp oil are also included.

We constructed similar baskets for the Spanish Latin American countries, focusing on the cheapest staple foods consumed there (Table 1, see the data appendix for full details). The staple food in Mexico and the Andean countries was maize, and additional quantities of beans and meat were consumed there as well. In Argentina and Chile, wheat was the cheapest staple (as we will see below), but meat was also very inexpensive and was consumed in particularly large quantities in Argentina. ${ }^{11}$ When discussing real wages in Chile and Argentina, we will also show that moving to a 'low meat diet' has hardly any effect on the price level and the real wages there, because of these very low prices of meat. The quantities of consumption goods such as textiles, heating, and soap are taken from Western Europe.

Given the extension and diversity of the Spanish empire in the Americas, one would expect large regional variations in levels of prices and wages by region. Moreover, there were differences in labour institutions, transportation networks, and relative importance of the regions within the colonial economy. Therefore we collected data for as many locations as possible. Thanks to the pioneering research of many scholars who collected and published studies of wages and/or prices in individual cities, regions and countries, we could put together consistent time series for six different locations (see the data appendix). For the two colonial

\footnotetext{
10 See the discussion by Bauer (1979a,b) and Loveman (1979).

11 This pattern is confirmed by the relative prices in the two regions: in Mexico a kilogram of maize was much cheaper than a kilogram of wheat: in the 16 th and 18 th centuries the difference is about $30 \%$ of the wheat price, in the 17 th century the gap is almost $50 \%$. As a consequence, Mexican consumers had great incentives to favour maize, even though its nutritional value per kilogram was slightly lower than that of wheat (in terms of proteins the difference is about $20 \%$ ). Also, in Peru, maize tended to be one-third cheaper than wheat, but the differential was declining. Further to the south, in Chile and Argentina, wheat was much cheaper than maize, and consumers chose a wheat-based diet (Johnson, 1990; Larrain, 1990).
} 
Table 1

Prices of wheat and corn in Spanish Latin America, 1525/1574-1775/1820 (in grams of silver per kilograms).

\begin{tabular}{|c|c|c|c|c|c|c|c|c|}
\hline & \multirow{2}{*}{$\frac{\text { Argentina }}{\text { Wheat }}$} & \multirow{2}{*}{$\frac{\text { Bolivia }}{\text { Maize }}$} & \multicolumn{2}{|l|}{ Chile } & \multicolumn{2}{|l|}{ Mexico } & \multicolumn{2}{|l|}{ Peru } \\
\hline & & & Wheat & Maize & Wheat & Maize & Wheat & Maize \\
\hline $1525 / 1574$ & - & - & - & - & 0.38 & 0.20 & 1.08 & 0.84 \\
\hline $1575 / 1624$ & - & - & - & - & - & 0.71 & 1.66 & 1.32 \\
\hline $1625 / 1674$ & - & - & 0.98 & 1.78 & 0.97 & 0.68 & 2.14 & 1.44 \\
\hline $1675 / 1724$ & 1.10 & 0.89 & 1.57 & 2.22 & 1.35 & 0.59 & 2.93 & 1.58 \\
\hline $1725 / 1774$ & 0.85 & 1.76 & 1.12 & & 1.09 & 0.81 & 2.14 & 1.37 \\
\hline $1775 / 1820$ & 0.94 & 1.64 & 1.00 & & 1.17 & 1.19 & 2.10 & 1.99 \\
\hline
\end{tabular}

Sources: see appendix.

pillars, Mexico and Peru, the data are the most abundant and extensive; for the fringe areas data are scarcer and often only available for the (late) 17th or 18th centuries. In the case of the viceroyalty of New Spain - present day Mexico - we have the most complete set of data, covering the three centuries between the Conquest in the 1520s and War of Independence (1810-1821). For the Viceroyalty of Peru, the datasets are more fragmented: there is sizable information on wages in the main silver mining city of Potosi (Upper Peru, now Bolivia), but before the 18th century price data are rather scanty for this region. Colombia is another example of relatively good wage data (for the 17th and 18th centuries) with poor price data. For Peru proper (Arequipa and Cuzco), the situation is the reverse: price data abound, but wage data only start in the late 17th century (apart from one observation for miners at about 1600). In the case of Chile, abundant price data exist while wage information (for the North) only starts in the late 17th century. Finally, for Argentina (Buenos Aires), there are a few wage data starting in the 1770s, and a limited set of price data.

These price and wage data sources are consistent with the ones used in European research: institutions such as monasteries, colleges, hospitals, and city governments are well represented. Government regulations (linked to systems of coercion) are also important sources. Almost all wage data refer to unskilled construction labourers or miners (in Potosi and Northern Chile); as is well known, also European research has focused on unskilled (and skilled) labourers in the construction industry. Similar to the European scholarship, prices are either retail or wholesale depending on the source (see appendix for details). Almost all data we use are based on large urban settings (Mexico City, Lima, Potosi, and Buenos Aires) and therefore not representative of the country as a whole. In most cases prices and wage levels would have been lower in the countryside; however, we only have limited rural information. Once again, this is very similar to other real wages studies that mainly analyse data from large cities (see for example Allen et al., 2011 for London, Amsterdam, Beijing, Canton and Tokyo).

All price and wage data were converted into modern units and in grammes of silver. Although the monetary unit used throughout the period was the peso of eight reales, debasements did occur throughout the colonial period. Moreover, depending on the mint in question, the silver content varied. We have been able to convert all the prices and wages into silver grams, according to the royally stipulated silver content of the peso (Burzio, 1958; Romano, 1998).

\section{Price developments}

Maize and wheat were the main staples of the (urban) diet, and their price evolution dominated the cost of living in the places we studied. Maize was an indigenous crop, the staple food in Mexico, but also grown on a large scale elsewhere. The history of its price has been the subject of substantial research, so we can trace its long-term development rather well (Borah and Cook, 1958; Garner,

Table 2

Bare-bones baskets in Europe and Hispanic Latin America.

\begin{tabular}{|c|c|c|c|c|c|c|c|}
\hline & \multirow[t]{4}{*}{ Good } & \multirow[t]{4}{*}{ Unit } & \multirow[t]{4}{*}{ Calories } & \multirow[t]{4}{*}{ Protein } & \multirow[t]{4}{*}{ Europe } & Mexico & \multirow[t]{2}{*}{ Argentina } \\
\hline & & & & & & \multirow{2}{*}{$\frac{\text { Peru }}{\text { Bolivia }}$} & \\
\hline & & & & & & & \multirow[t]{2}{*}{ Chile } \\
\hline & & & & & & Colombia & \\
\hline \multirow[t]{5}{*}{ Food } & Wheat/oats & $\mathrm{kg}$ & 3.370 & 88 & 155 & & 132 \\
\hline & Maize & $\mathrm{kg}$ & 3.370 & 70 & & 165 & \\
\hline & Beans & $\mathrm{kg}$ & 1.455 & 71 & & 45 & \\
\hline & Meat (beef/pork) & $\mathrm{kg}$ & 2.500 & 200 & 5 & 35 & 105 \\
\hline & Butter & $\mathrm{kg}$ & 7.286 & 7 & 3 & & \\
\hline \multirow[t]{5}{*}{ Other } & Soap & $\mathrm{kg}$ & & & 1.3 & 1.3 & 1.3 \\
\hline & Linen/cotton & $\mathrm{m}$ & & & 3 & 3 & 3 \\
\hline & Candles & $\mathrm{kg}$ & & & 1.3 & 1.3 & 1.3 \\
\hline & Lamp oil & $\mathrm{kg}$ & & & 1.3 & 1.3 & 1.3 \\
\hline & Fuel & M BTU & & & 3 & 3 & 3 \\
\hline Total calories (daily) & & & & 1.936 & 1.943 & 1.938 & \\
\hline Total protein (daily) & & & & 60 & 60 & 89 & \\
\hline
\end{tabular}

Sources: For Latin America, see appendix; Europe: Allen, 2001 and Allen et al., 2011. 
Table 3

The average cost of the bare-bones baskets in Spanish Latin America and Europe, 1525/1574-1775/1820 (in gram of silver).

\begin{tabular}{|c|c|c|c|c|c|c|c|c|}
\hline & Argentina & Bolivia & Chile & Colombia & Mexico & Peru & London & Leipzig \\
\hline $1525 / 1574$ & - & - & - & - & 88 & $344^{\mathrm{a}}$ & 84 & 119 \\
\hline $1575 / 1624$ & - & - & - & - & 281 & 545 & 168 & 194 \\
\hline $1625 / 1674$ & - & - & 461 & - & 308 & 666 & 220 & 142 \\
\hline $1675 / 1724$ & 234 & 350 & 545 & 306 & 266 & 699 & 206 & 153 \\
\hline $1725 / 1774$ & 190 & 631 & 435 & 300 & 316 & 598 & 223 & 188 \\
\hline $1775 / 1820$ & 255 & 509 & 437 & 316 & 448 & 729 & 356 & 332 \\
\hline
\end{tabular}

Sources: For Latin America, see appendix; London and Leipzig: Allen, 2001 and Allen et al., 2011.

a $1564 / 1575$ only.

1985; Garner, 1990). The development of the price of maize clearly reflects the long-term changes in price levels in the world economy (Table 1). During the 16th century, maize prices in Mexico rose strongly - by at least a factor of four - a fact well established by the literature (Garner, 1985). The increase continued into the 1620s; then followed stability, and in the second half of the 17th century and the first decades of the 18th century modest deflation. In the second half of the 18th century, prices rose again, but at a much less rapid rate then in the 16th century. Similar long-term fluctuations are found in the price of wheat in Peru and Chile (Table 1). These long-term fluctuations very much resemble European (and perhaps even global) trends in price levels.

Weighing the prices of the different commodities by their relative importance in the consumption basket leads to estimates of the total costs of the bare-bones basket (Table 2). The large differences in price levels within Spanish Latin America are immediately apparent: during the 17th and 18th centuries, the average cost of the bare-bones basket in Mexico fluctuated between 250 and $350 \mathrm{~g}$ of silver (Table 3), with occasional peaks above the $450 \mathrm{~g}$ line. In Peru, on the other hand, a level of 600 to $800 \mathrm{~g}$ of silver became normal during the 17th century. Prices in Potosi - part of the same economic system as Peru - were at roughly the same level. Chile was also quite expensive, but its relative price level fell a bit compared to that of Bolivia and Peru. Colombia, on the other hand, was much less expensive than the southern Andean countries, and much closer to the price level of (Table 3). The lowest price level was found in Argentina. ${ }^{12}$

Table 3 also demonstrates that, from the final decades of the 16th century onwards, living in Latin America was costly in terms of silver. Prices elsewhere were much lower - that is, silver was less cheap. Between 1600 and 1775, the cost of the bare-bones basket in Europe fluctuated between 150 and $250 \mathrm{~g}$ of silver, lower than in Mexico, which was the 'cheapest' place in Hispanic Latin America. Only in Argentina did the price level approach the European level. Moving inland and closer to the silver mines of Potosi, prices rose - or the value of silver declined. This phenomenon is expected: in Peru and Potosi, prices were extremely high. Chile falls in the middle: its main export markets were Peru and Bolivia (Potosi). Hence, as one would expect, prices of most commodities were lower at origin than in the demanding region. The relative price levels were, it seems, determined by the closeness to the main mining centre of Potosi. This effect diminished in the second half of the 18th century probably associated with the sharp decline of the mining output. As a consequence, Potosi lost its prominent role in the Spanish American economy (Bakewell, 1984; Tandeter, 1993).

One can argue that some kind of 'Dutch disease' effect was present in Latin America in this period. Because of its closeness to the sources of world silver, prices were on average much higher than elsewhere in the world economy. By contrast, during much of the Early Modern period, prices in Asia - the final 'sink' of much of the silver mined in Spanish America - were on average even lower than in Europe (Allen et al., 2011). Moreover, the fall in the relative prices of imported commodities such as linen textiles may also have depressed domestic production, in particular during the 18th century when trade became increasingly free from colonial constraints. Various authors (Brown, 1990: 183-5; Tandeter and Wachtel, 1990: 203-7; Larrain, 1990: 123) present evidence for similar price trends in other imported commodities such as spices, paper, sugar and iron. The fact that Latin America was a very expensive place to live and work might have had long-run effects on its development trajectory. ${ }^{13}$

\section{Nominal wages}

The next step is to look at the evolution of nominal wages. The longest time series refers to Mexico (see also the summary of wage trends in Gibson, 1964: 249-252). It shows very strong growth of nominal wages between the 1520s (the first data are related to coerced labour by Indians) and the 1620s, followed by long-term stability - with only occasional and small changes - during the $1630-1800$ period. ${ }^{14}$

\footnotetext{
12 This result is based on a very limited number of price series for the period before 1780, however. Even though we can be sure that wheat and in particular meat were quite cheap there, the estimated cost of an Argentinean bundle series is highly tentative because price information for other commodities only starts in that year.

${ }^{13}$ Asia, with its radically different starting point of low prices and low wages, could embark on a labour-intensive development path, a possibility that was not open to the Latin American economies; see Sugihara (2007).

${ }^{14}$ For the 18th century, we have used the data of wages of construction workers by Quiroz (2005) pointing to a wage level of 3 reales per day. In Northern Zacatecas similar wages were paid in the period 1749-1810: Garner (1990: 101) quotes wages for unskilled building labourers of 6 to 12 pesos per month (equal to 2.4 to 4.8 reales per day, assuming 20 working days per month) and for craftsmen of 12 to 28 pesos per month (4.8-11.2 reales per day); Van Young, 1992 also has wage data for 18th century building labourers in Mexico City which are generally higher than 3 reales per day. The estimated level of 3 reales per day is higher than wages paid in textiles and in agriculture, which may have ranged from 1 to 3 reales per day; 1.5 to 2 was probably the average daily income (all data relating to the 18th century; see the discussion in Salvucci, 1987: 26-28).
} 
Table 4

The average nominal wages of unskilled labourers in Spanish Latin America and Europe, 1525/74-1774/1820.

\begin{tabular}{|c|c|c|c|c|c|c|c|c|}
\hline & Argentina & Bolivia & Chile & Colombia & Mexico & Peru & London & Leipzig \\
\hline $1525 / 1574$ & - & 9.4 & - & - & 0.7 & - & 3.5 & 1.9 \\
\hline $1575 / 1624$ & - & 10.2 & - & - & 3.5 & 7.4 & 5.7 & 2.6 \\
\hline $1625 / 1674$ & - & 12.6 & - & 3.2 & 7.9 & 10.2 & 8.5 & 4.0 \\
\hline $1675 / 1724$ & - & 12.8 & 10.3 & 5.1 & 8.7 & 10.2 & 10.1 & 3.7 \\
\hline $1725 / 1774$ & - & 12.8 & 10.4 & 5.1 & 9.2 & 10.9 & 11.0 & 3.4 \\
\hline $1775 / 1820$ & 25.3 & 12.2 & 12.8 & 6.1 & 9.1 & 15.4 & 15.0 & 3.6 \\
\hline
\end{tabular}

Sources: For Latin America, see appendix; London and Leipzig: Allen, 2001 and Allen et al., 2011.

The relatively high nominal wages that of Mexico in the 17th and 18th century are also found in the rest of the continent, with the notable exception of Colombia, where nominal wages are at least a third lower than in New Spain. Wage data in Bolivia and Chile (and for Peru at about 1600) are for mine workers and may overstate 'normal' wages. For Bolivia, we use the daily wages paid to mita workers in Potosi as set by the government from the 1570s onwards (Bakewell, 1984). In the case of Chile, these are the wages of miners in El Norte Chico, the northern part of the country, for occupations involving ore cutting and transportation (Carmagnani, 1963). The Peruvian wage series is a mix of two sets of data: for mita workers in the mines at about 1600 (Stern, 1982), and after 1670, for porters in Lima (Macera, 1992). Porters' wages were as high as those of Mexican building workers.

Nominal wages in Peru and Bolivia show the same pattern of sharp increase before the 1630s and near stability in the rest of the period. In Chile, wages increased markedly at about 1700, which (after 1729) brought Chilean wages to the level of Potosi. In general, nominal wages in this region were higher than in Mexico, but the difference was 'only' about a quarter to a third. Nominal wages in Argentina were much higher than anywhere else in Spanish America and in Europe (Table 4). In the 1770s unskilled workers in Buenos Aires earned about 17 pesos per month, rising to 33 pesos in the 1810s (Barba, 1999; Coatsworth, 1990: 29; Johnson, 1990: 163-4). By the 1770s, nominal daily wages in Buenos Aires were $20 \mathrm{~g}$ of silver, twice the level in Mexico, and more than 60\% higher than in Potosi. This gap increased even further between 1770 and 1820.

The comparison with Europe shown in Table 4 further underlines the high level of nominal wages found in Hispanic Latin America (and therefore the potential 'Dutch disease' effect). In Peru, for example, nominal wages were at about the same level as in London, with Amsterdam the 'wage leader' in Western Europe. After 1600, Mexican nominal wages were still two to three times higher than in the European 'periphery', here represented by Leipzig. ${ }^{15}$

\section{Real wages}

The ratio between nominal wages and the costs of the basket of consumption goods is obviously the real wage, measured in terms of the 'welfare ratio', which was calculated, following Allen (2001) and Allen et al. (2011). This estimation assumes a household of 4 people (but only 3 consumption baskets, as per capita consumption of children is lower), and a 5\% addition for rents (not included in the original basket). Moreover, it is assumed that workers are employed 250 days per year, an assumption to which we return later on.

The aim of these estimates is to assess whether the wage is sufficient to support a household at the minimum level. A welfare ratio of one implies that the wage of the unskilled labourer is barely enough for the consumption of this family. If the welfare ratio is below one, the nominal wage is insufficient for feeding, clothing, and housing such a family. ${ }^{16}$

Fig. 1 and Table 5 present the main results. Mexican real wages, the only series that almost covers the entire period of three centuries, followed an inverted-U curve: in the 16th century, when wages were set by viceroyalty and coercion was quite intensive, real wages were insufficient to cover the maintenance of a family. But they slowly increased, and after about 1590 surpassed this threshold. During the liberalization of labour market in the first decades of the 17th century, they increased sharply, and at their peak, at about 1700, the welfare ratio was roughly 3, not much below the levels realized in North Western Europe. By comparison, the same 'welfare ratio' for English (in fact London) workers was more stable at about 3-4 during the whole 1525-1820 period. The high British welfare ratio has been interpreted as the result of a highly developed commercial economy with a high level of labour productivity - in a way, preparing itself for the Industrial Revolution (Allen 2009, Allen 2001, Van Zanden, 2009). That the purchasing power of Mexican workers in the (late) 17th century and (early) 18th century almost equalled that of London labourers is a striking result. This high standard of living did not persist: after about 1770 a strong decline of real wages set in, caused by rapidly rising prices (whereas nominal wages remained the same), and at about 1810 the welfare ratio fluctuated at about 1.

\footnotetext{
${ }^{15}$ A short note on the wages of skilled labourers and the implied skill premium: in Mexico, skilled labourers such as carpenters earned, both in the late 16th and in the 18th century, about twice the wage of an unskilled labourer (Garner, 1990: 101; Gibson, 1964). For Buenos Aires a similar skill premium, close to 100\%, is reported (Coatsworth, 1990: 29). For workers contracted via the encomienda system in Peru, the wage gap was much higher, up to 300-400\% (at about 1600) (Stern, 1982). The skill premium found in Mexico and Argentina is somewhat higher than the Western European average. In England and Holland, the level is about 50\%; however the Latin American premium was relatively similar to the one Madrid (also 100\%) (Van Zanden, 2009: 155).

${ }^{16}$ Below 1 may also mean that the subsistence of the family is dependent on the income earned by the women and/or the children, or that they receive an income from non-wage activities, for example in agriculture.
} 


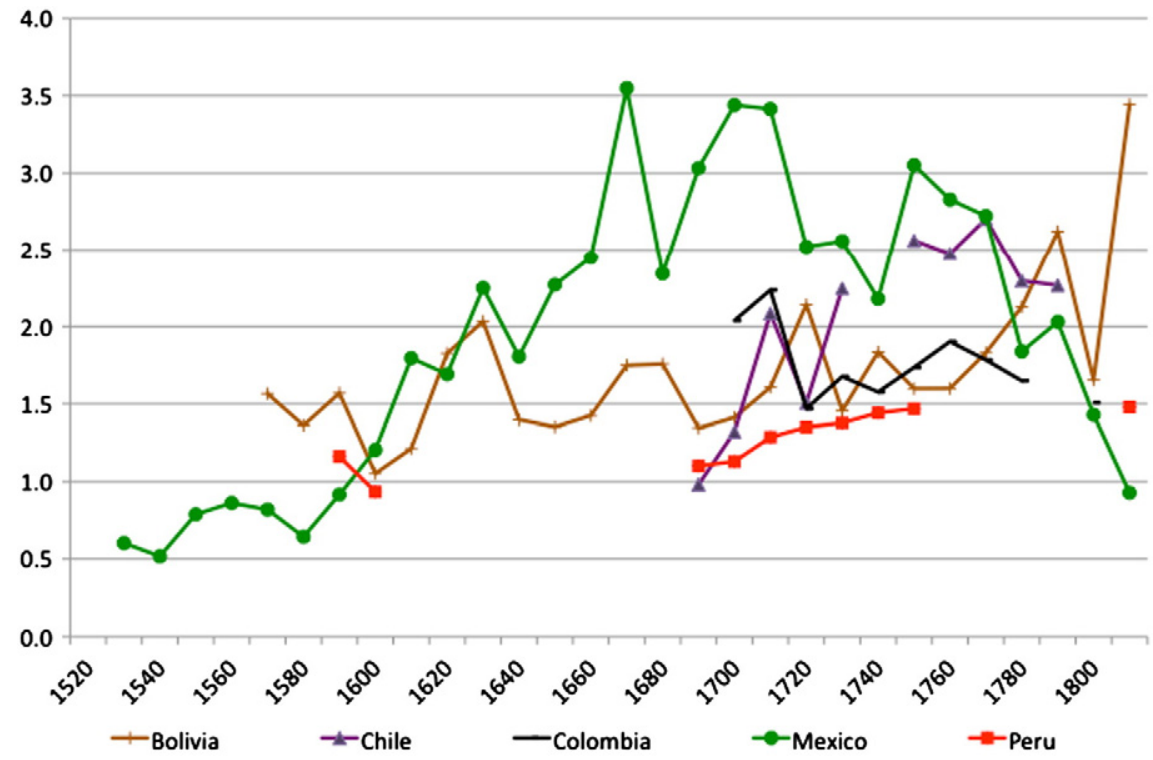

Sources: see appendix

Fig. 1. Real wages in bare-bones baskets, 1520s-1810s (10-year average). Sources: see appendix.

The development of the real wage in the Andean countries contrasted sharply with that in Mexico (Fig. 1). First we look at the two countries for which we have data of wages of unskilled labourers: Peru and Colombia. In Peru, we find level of real wages in the (late) 17th century/early 18th century that are only barely above subsistence. It is only in the 18th century that we find a, still moderate, rise above this level. It suggests that in the 17th century labour scarcity was less a problem in Peru, perhaps due to the less dramatic decline of the Indian population there (see below). Colombian real wages are only available for the 18th century, and then show a level substantially higher than subsistence.

We have real wage data of two mining centres, northern Chile and Potosi. For 16th and 17th century Potosi we have only sporadic price data, which the price levels there were very similar to that of Peru, with which it was closely connected. We therefore often had to use Peru prices to establish real wages in Potosi for the period before 1720. These results in estimates of the real wages of mita workers that fluctuate between 1 and 2 during most of the period - only occasionally are real wages higher. ${ }^{17}$ For the period 1585-1650 we also have estimates of the nominal wages of free wage labourers in Potosi. Free labourers, or mingas, enjoyed earnings that were twice to three times those of mitayos; moreover, they worked fewer hours per day (only from 10 to 4 (Bakewell, 1984: 122-124)). In 1600, at the peak of silver production, the free market wage had increased to 11-14 reales per day, but afterwards it did not climb any further. It stabilized at about 11-12 reales (in 1615, 1630, and 1637) when the official running wage rate (for mitayos) was still 4 reales (Bakewell, 1984: p. 125). In nominal terms, with their daily wage of about $35 \mathrm{~g}$ of silver, the miners of Potosi were perhaps the best-paid workers in the world - their welfare ratio ranged from 3 to 6 . However, giving the dangers of this kind of work (the accidents underground, the diseases the miners often suffered from), these real wages are not comparable to those of the construction workers that are studied in the other countries. If we divide the real wage by two, we probably get a more comparable estimate - which is then 'below subsistence' for most of the mita-workers, and between 1,5 and 3 for the free labourers. ${ }^{18}$

Mining in Chile was not as remunerative as in Potosi: mining activities (of predominantly gold) were of small scale and did not put much pressure therefore on local labour markets. Real wages there show a pattern similar to that of the other Andean countries, of a rise from about 1 in 1700 to 1.5 in the second half of the 18 th century.

Argentina, again, is a special story: according to the rather fragmentary data for the post 1770 period, the cost of living was relatively low here, whereas nominal wages (of European workers) were much higher than in the rest of the continent. The real wage was, therefore, much higher than anywhere else, including London. Between 1770 and 1800 the welfare ratio fluctuates between 6 and 16, mainly because of the extremely low prices of meat and wheat. To check these results, we also built estimates

\footnotetext{
17 During the boom in silver mining, in 1603, a miner could buy more than $43 \mathrm{~L}$ or $31 \mathrm{~kg}$ of maize with his daily wage, far more than in the 18 th century, when the real wages fell to 5 and $10 \mathrm{~kg}$ of maize (calculated from Bakewell, 1984: 101-103). This suggests that real wages were very high during the boom, and fell gradually when the industry started to contract - again, following the market.

18 The issue is how to compare wages of miners with those outside the mines. Hatcher (1993: 399-402) has documented that wages of English miners in the early modern period were about $50 \%$ higher than those of unskilled construction workers in the same region. In Mexico, the difference may have been higher: the few observations available in the literature wages in Zacatecas (in northern Mexico) suggest that in 1550 and 1600 nominal wages of miners were between 3 to 4 times the level of that of unskilled labourers in Mexico City (Bakewell, 1971). In the 18th century this gap may have been similar: miners earned on average 4 reales per day, construction workers in Mexico city 3 reales per day, and hacienda peons 1,5 tot 2 reales (Brading, 1971: 147), but these figures do not include the share in the ore that the workers received as well, implying that the total wage gap was probably as large as in the 16 th century (see also Brading, 1971: 148).
} 
Table 5

Average welfare ratios in Spanish Latin America and Europe, 1525/74-1774/1820.

\begin{tabular}{|c|c|c|c|c|c|c|c|c|}
\hline & Argentina & Bolivia & Chile & Colombia & Mexico & Peru & London & Leipzig \\
\hline $1525 / 1574$ & - & - & - & - & 0.76 & - & 3.22 & 1.89 \\
\hline $1575 / 1624$ & - & - & - & - & 1.20 & 1.10 & 2.67 & 1.64 \\
\hline $1625 / 1674$ & - & - & - & - & 2.36 & - & 3.02 & 1.76 \\
\hline $1675 / 1724$ & - & 2.95 & 1.46 & 1.80 & 3.03 & 1.18 & 3.86 & 1.48 \\
\hline $1725 / 1774$ & - & 2.95 & 1.45 & 1.78 & 2.99 & 1.18 & 3.84 & 1.29 \\
\hline $1775 / 1820$ & 9.47 & 2.20 & 2.40 & 1.58 & 1.86 & 1.48 & 3.31 & 0.71 \\
\hline
\end{tabular}

Sources: For Latin America, see appendix; London and Leipzig: Allen, 2001 and Allen et al., 2011.

for real wages in Buenos Aires in the first half of the 19th century. They show a decline from the very high levels of the late 18th century, but the level remained much higher than levels observed elsewhere (fluctuating between 3 and 6) (see also Arroyo Abad, 2008; Taylor, 1997). ${ }^{19}$

\section{Interpretation: the Mexican inverted U-curve}

How plausible are these results? Only for Mexico can we follow the development of real wages during these three centuries, so we will concentrate on the Mexican results first. The inverted U-curve that we find for this city is a bit similar to the behaviour of real wages in Europe after the Black Death and the gradual recovery from this in the period between 1450 and 1600 . The longterm trends in real wages (in bare-bones subsistence baskets) between Mexico and two selected cities Western Europe, London and Firenze are presented in Fig. 2. The demographic shocks were different in nature and intensity in these locations. In Europe, the Black Death led to a decline in population levels of about 35-50\% on average. However, in England the plague was exceptionally severe: according to recent estimates total population decline including the Great Famine of 1315-1317 was about 60\% (Broadberry et al., 2010). In Northern Italy the decline was at most 50\%, probably less, but still very impressive. The decline of Mexican population in the century after Spanish encounter was even more dramatic, as we pointed out already.

The long-term increase in the real wage in Mexico City - from perhaps as low as 50\% of the subsistence minimum in the 1530 s and the 1540s to between 3 and 3.5 that level at about 1700 - indeed suggests a response to a very sharp depopulation that is similar to Western Europe. The main difference is that it appears to take much longer - about a century - before real wages have attained the much higher level consistent with the sharp depopulation after 1520. One possible explanation is that until the 1620s wages were kept at an artificially low level; the point of the coercive labour institutions developed by the Spanish was to keep labour costs down. But data problems (the 16th century data are rather scarce and from a range of sources - see Borah and Cook, 1958) may also play a role in explaining the perhaps rather puzzling development of real wages in 16th century Mexico.

We hypothesize that the gradual 'liberalization' of the labour market in the late 16th and early 17th century - a well documented fact - probably brought real wages much closer to the 'true' market value of the labour. Such a delayed market reaction is not unprecedented: we observe a similar pattern in England during the 14th century. In 1348 the government introduced the Statute of Labour that fixed a maximum wage and requiring all fit men to work; in a similar way, the state was used as an instrument to keep wages down in a period of labour scarcity. This system collapsed in the 1380s, however, after the Peasant revolt of 1381 partly motivated by discontent about the Statute of Labour. The government responded by relaxing these policies resulting in a rapid increase in both nominal and real wages (Hilton, 1973). A similar scenario is likely for Mexico: first the Spanish tightened labour regulations to keep wages down. As it became evident that such a policy was inefficient, the crown started to liberalize the labour market. This interpretation is rather speculative however, and more research is required to find out what happened in this period.

Overall, real wages in Mexico increased by a factor of four between the mid 16th and the early 18th century (see Table 6), or by a factor of three if we assume that real wages were artificially low during the mid 16th century and that their 'proper' rate should have been close to subsistence. In London and Firenze (and in other parts of Europe), initial real wages were much higher but the total increase was by a factor of two.

The question remains whether the behaviour of real wages is mostly explained by the changes in population. To explore this, we use a simple production function framework to evaluate the role of capital, labour, and total factor productivity during the depopulation events presented earlier. Following Persson (1991) and Hoffman (1996), we assume a Cobb-Douglas production function with only capital (including land) and labour as factors of production with shares between $40 \%$ and $60 \%$. Assuming no changes in the capital stock and the cultivated area, ${ }^{20}$ a decline of the labour force of $75 \%$ yields a $100 \%$ increase in real wages. If we allow for

\footnotetext{
19 A final note on the large amount of meat consumed according to the Chilean and the Argentinean baskets: if we assume a 'low meat' diet consisting of 'only' $35 \mathrm{~kg}$ of meat (instead of $105 \mathrm{~kg}$ ), and assume that these calories are supplied by wheat, our estimates of real wages do not change much. In Chile, the difference in real wages is only $4 \%$ on average before 1750 and $22 \%$ for the same wages between 1750 and 1800 . In Argentina between 1770 and 1800 the 'low meat' basket is $10 \%$ more expensive than the diet with $105 \mathrm{~kg}$ of meat. These changes after 1800 , however, when the relative price of meat increases rapidly, and the 'low meat' diet becomes much cheaper.

20 Evidence on land use during colonial times is limited, so we cannot insert an estimate of the change of the cultivated area. The quantity and quality of land may have declined however, because the collapse of the population was accompanied by capital destruction as evidenced by the disappearance of the intervalley canals and terraces in Peru and the decline of agriculture in the Mexican wetlands (Assadourian, 2006).
} 


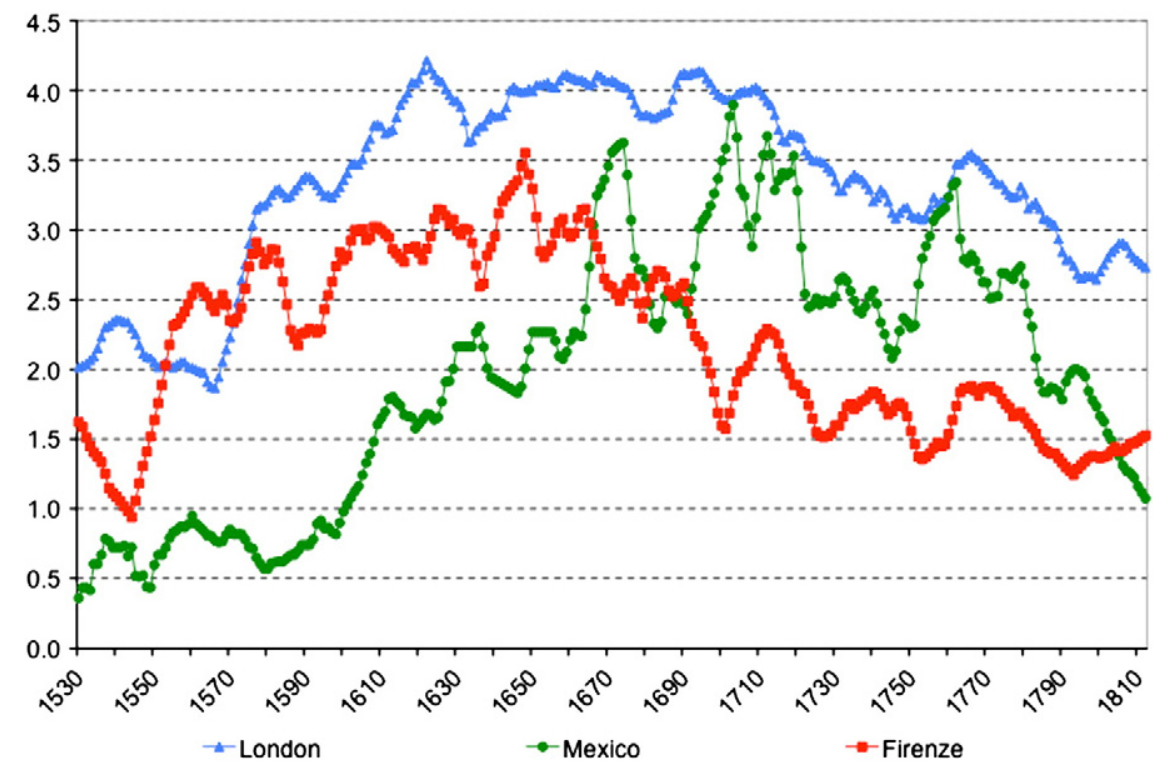

Sources: for Latin America: see appendix; Firenze and London: Allen 2001 and Allen et al. 2011.

Fig. 2. Real wages during and after demographic shocks, Mexico City - 1530-1813, London and Firenze - 1330-1613 (11-year moving averages). Sources: for Latin America: see appendix; Firenze and London: Allen, 2001 and Allen et al., 2011.

the capital stock to fall by say $20 \%$, then the drop in population must be even larger -about $80 \%$ - for wages to double. As the population of Tuscany and England fell by 'only' 50-60\%, the consistent increase in real wages is 60\% assuming constant capital stock or even lower when capital stock declines. This simple exercise suggests that the two-fold increase in real wages in England and Tuscany was also the outcome of a strong increase in total factor productivity in the 150 years following the Black Death in both countries (see Persson, 1991).The rise in Mexican real wages was much higher - by a factor of 3 to 4 . For real wages to triple, the decline in total population must amount to $90 \%$ with constant capital stock. With a $20 \%$ reduction in capital stock the population had to decrease by $91 \%$. In conclusion, our real wage estimates are consistent with the population figures of the 'high counters'.

It is more difficult to account for the sharp decline in Mexican real wages during the 18th century - a decline by about 60-70\%. Between the mid 17th century and the end of the 18th century, the Mexican population increased by about 100-150\%, which would be consistent with a decline of real wages by 30-35\% (with constant capital stock). The evidence points to the fact that the high real wages of the 1680-1750 period were a temporary premium, not sustained by a productive economy but the result of temporary scarcities on the labour market. A sharp downturn of real wages after the recovery of the population also occurred in large parts of Europe. Only in England and the Low Countries did changes in the structure of the economy make it possible to sustain the relatively high levels of real wages. The Mexican experience is not an outlier in history as it clearly fits into the 'normal' pattern found in Europe. Moreover, it is confirmed by anthropometric research, which shows a decline in the stature of Mexicans from about 1750 onwards (Challú, 2010). At about 1800, with a population of about 5 million, real wages were back to subsistence - in other words, the economy was able to accommodate only about 5 million people, compared to 9 to 18 million in 1500. Whereas in Western Europe each successive Malthusian 'crisis' occurred at higher levels of population density (the population in 1800 was much larger than in 1600, which was again larger than in 1300), pointing at a gradual growth of productivity, the 'peak level' of Mexican population in 1800 was still significantly lower than before European contact.

Table 6

Comparison of real wages (as welfare ratios) and GDP per capita in Latin American countries at about 1820.

\begin{tabular}{|c|c|c|c|c|}
\hline & & \multicolumn{2}{|c|}{ GDP per capita (1990 dollars) } & \multirow{2}{*}{$\frac{\text { Real wages }}{1800 / 1820}$} \\
\hline & & 1820 & 1900 & \\
\hline Argentina & 1249 & 2756 & 6.54 & \\
\hline Uruguay & & 1004 & 2219 & - \\
\hline Chile & & 607 & 2194 & 2.26 \\
\hline Mexico & & 693 & 1366 & 1.29 \\
\hline Colombia & & 346 & 973 & 1.51 \\
\hline Peru & & - & 686 & 1.48 \\
\hline Venezuela & 347 & 821 & - & \\
\hline
\end{tabular}

Sources: GDP per capita: Prados de La Escosura (2009), Table 4 and Maddison (2001); Real wages: see appendix. 


\section{Interpretation: the other regions}

In other regions we find real wages greatly above subsistence levels in the mining areas of Bolivia and Chile, and in Argentina. That in Potosi real wages are quite high is perhaps expected: the system of coerced labour had limitations forcing mineowners to pay a relatively high wage in a situation of labour scarcity. As mentioned already, the infamous mita system was a mixture of coercion and monetary incentives but the government-set minimum wages were in nominal terms relatively high. Moreover, in real terms, they were still substantial, reflecting the market forces at the spot. Especially the free labourers were paid quite well during the great boom in silver mining. In nominal terms, with their daily wage of about $35 \mathrm{~g}$ of silver making the free miners of Potosi were the best-paid workers in the world and, in real terms, their wages were relatively high. The sizable wage gap between free and mita labour induced Indians to increasingly devise ways to evade forced labour. Forms of resistance ranged from flight and deceit to clever politics. The result was a reduction of the pool of labourers subject to draft. The Spaniards adapted to this situation by gradually switching to free wage labour (Stern, 1982: 143-144).

Real wages of free workers in Potosi therefore appear to have followed a similar long-term trend as those in Mexico; perhaps the pattern was even more extreme than there. Developments of wages in Chile followed a similar evolution, with considerable time lag. Mining started much later: the real boom in copper mining only occurred in the 18th century. While initially debt-labour (peonage) in small-scale gold mining dominated the labour supply, the very rapid growth of the population of Chile in the 18th century reversed labour scarcity to surplus. Again, we see real wages following this trend. In the second half of the 18th century, the population of Chile increased so strongly that insufficient labour supply was no longer a problem and free wage labour (by mestizos) prevailed (Carmagnani, 1963, 1973). The increased labour supply even resulted in the comparatively rare phenomenon of declining nominal wages in the 1780s and 1790s (Carmagnani, 1963).

In the southern cone, at the end of the 18th century, we find extremely high real wages in Buenos Aires. The causes are well known: labour scarcity in a situation of land abundance resulting in high output levels of cheap agricultural commodities, and good access to cheap import goods. The wage structure there is probably similar to that found in Australia, Canada, and the US in the early days of their colonization. The very high wages were obviously the product of markets, and reflect the relative scarcity of labour.

Are these results consistent with other data on Latin American economic development? At about 1800 we find large differences in real wages, ranging from the very high levels in Buenos Aires to the near subsistence levels of Mexico. This pattern is in agreement with recent estimates of the GDP per capita of these Latin American countries as presented by Prados de la Escosura (2009) (Table 6). Argentina clearly stands out with a much higher GDP per capita (at the same level as European countries) than the other countries in the region (with the exception of Uruguay). Chile is in terms of both real wages and GDP a 'middle income country' in the region, and Colombia is clearly relatively poor on both counts. Mexico is a problem here: its estimated GDP per capita is higher than that of Chile, but its real wage is the lowest. Note that our estimates of real wage developments are not consistent with Maddison's figures for economic growth in Latin America between 1500 and 1800 (see below).

The same pattern emerges from the scarce data on the biological standards of living. In Argentina, people were extremely tall (about $170 \mathrm{~cm}$ on average), even taller than most Europeans. In Peru and Colombia average heights were much lower $(163-165 \mathrm{~cm})$ in the early 19th century, still sizable by European standards. Mexican heights probably fell in between (see Baten and Carson, 2010 for an overview). For Mexico, other evidence supports the inverted U-curve evolution of real wages. Living standards increased in the 16th century as food supply was improving according to Cook and Borah (1979: 129-176). In addition, the decline in Mexican real wages after 1750 is consistent with the evidence on the development of heights found by Challú (2010).

The new estimates of real wages may also be the starting point for reconsidering the current views on long-term economic growth in Latin America. Quantitative research on economic growth before 1820 is scarce. Thus, the estimates presented by Maddison (2001) in his global dataset are perhaps the best summary of the state of research. He assumes that per capita GDP of Latin America grew very slowly between 1500 and 1600. From an income level of 416 in 1990 dollars, it climbed to $\$ 438$ by the turn of the 17th century. GDP then accelerated to $\$ 527$ in 1700 and $\$ 691$ in 1820 . This was much lower than in Western Europe with an average of $\$ 1.234$. These figures are based on the assumption that the income level per ethnic group (Indians, European immigrants, and mestizos) remained the same, but that during the 1500-1820 period the ethnic composition of the population changed (Maddison, 2001: 250).

It is doubtful whether this approach results in reliable estimates of the growth record of Latin America. First, the ethnic categories were in practice somewhat fluid. For example, an Indian could become a mestizo within his lifetime. Moreover, while hierarchy existed, often mestizos and natives worked in similar occupations. Alcabala records prove their active market participation in colonial Peru. So prevalent was this practice that the Spaniards, unsuccessfully, imposed conditions to restrict market access to Indians (Tandeter et al., 1995). Moreover, the pattern of growth estimated by Maddison is clearly at odds with the large swings in real wages that we find here. Recent research on English GDP during the late Middle Ages has demonstrated that its development more or less followed real wages: the sharp decline of population after 1347 resulted in increases in both real wages and GDP per capita, and the recovery of the population during the 16th century lead to both some decline of real wages and a stagnation of per capita GDP (Broadberry et al., 2010). Perhaps a similar scenario is more likely for Mexico:

\footnotetext{
${ }^{20}$ Evidence on land use during colonial times is limited, so we cannot insert an estimate of the change of the cultivated area. The quantity and quality of land may have declined however, because the collapse of the population was accompanied by capital destruction as evidenced by the disappearance of the intervalley canals and terraces in Peru and the decline of agriculture in the Mexican wetlands (Assadourian, 2006).
} 
the collapse of population during the 16th century and early 17th century has probably resulted in an increase in GDP per capita. Cook and Borah (1979: 129-176) point to the improvements in the dietary conditions of the Indian population in the period 1500-1650, thanks to the increase in per capita food consumption. We find that this fact agrees with the evolution of real wages. In the late 18th century, levels of meat consumption in Mexico City were at an extremely high level of $150 \mathrm{~kg}$ per capita, much higher than in Western Europe; even in prosperous Holland meat consumption per capita was not higher than $27 \mathrm{~kg}$ (Van Zanden, 1999: 190). Meat prices were also very low in comparison with Europe, but this helps to explain only part of the difference (González, 2009). During part of the period, real incomes in Latin America may therefore have been higher than assumed by Maddison, and their development path was almost certainly different.

\section{Conclusion}

This paper was made possible by the diligent work of dozens of economic historians who over the last 50 years or so have collected a wealth of information on the development of prices and wages in the various parts of Spanish Latin America between the Conquest and the Independence. Our contribution has been to integrate these data into one coherent framework. Following a consistent methodology, this format allows for international comparison, in particular with Western Europe, but in principle also with the rest of the world. We have reconstructed the long-term evolution of the price levels measured as the costs of a barebones budget of a family and the nominal and the real wages of construction workers, miners and other 'unskilled' labourers in Mexico, Peru, Bolivia, Chile, Colombia, and Argentina.

Our main findings are that Latin American price experience was far from unique in historical perspective. The long-term evolution of prices was similar to the one experienced in Western Europe. The long 16th century (until the 1620s) witnessed a very strong increase in the price levels. This was followed by stability and in a few regions even decline during the second half of the 17 th century. In the 18 th century a renewed but much more modest rise in prices began. Despite the overall similarities in trends, we discover significant differences in absolute price levels within Latin America: prices in Mexico, Argentina, and Colombia were much lower than in Peru, Chile, and Bolivia. While silver flows could be the most obvious cause to explain these differences systematically, we find that the shift of importance of the silver production within colonial times did not affect the overall pattern. While silver flowed copiously from the Bolivian mines in Potosi, the commodities in the region were more expensive. However, when silver mining became more prominent in Mexico in the 17th and especially the 18th century, we observe no change in the relative price levels. Only towards the very end of the colonial period do we observe convergence in price levels within the region as a whole.

We were, however, primarily interested in the development of nominal and real wages as indicators of the standard of living of the population and of the productivity of labour. The wage data suggest that in the long-term, wages responded to market conditions. In particular, we find wages in Mexico reacted to changes in the supply of labour due to the dramatic decline of the Indian population in the century after Conquest, and the partial recovery during the 18th century. However, in the 16th century this response is probably delayed by coercive institutions. In mining centres of Bolivia and Chile, wages are also affected by changes in the demand for labour due to booms and busts. While labour scarcity was common throughout the Spanish empire in the Americas, the degree and causes varied by location. Common to all was the depopulation after Spanish contact; the mining boom in Bolivia and very high land/labour ratio in Argentina also positively affected real wages there. The real wage estimates presented here suggest that living standards may have increased substantially, a change that is quite clear for Mexico, for which we have the longest series and the best data. But the standards of living of free wage labourers in Potosi, of construction workers in 18th century Buenos Aires, and, to a much lesser extent, of Chilean miners in the same period, were also relatively high, and compared favourably with real wages of large parts of Western Europe. Real wages in Peru and Colombia, on the other hand, were not particularly high before the 1720s suggesting a distinct demographic development in the region.

These results provide important insights into the nature of the Latin American economy in this period. This was not a 'feudal' economy dominated by non-market institutions. The results clearly indicate that markets affected prices and wages. In particular, relative scarcity, most clearly of labour, clearly influenced the outcomes of market exchange. This does not imply that non-market institutions such as the mita and the encomienda for drafting labour were unimportant. However, Spanish authorities realized that coercion alone could not meet the labour demand: monetary incentives were almost always part of the labour relationship, which were often adjusted to prevailing markets conditions.

These findings also have consequences for our view on the long-term economic growth of Latin America in this period and in the 19th century. They strongly suggest GDP per capita has developed differently than estimated by Maddison (2001) in his pioneering research, and that the starting level at the eve of the 19th century may have been higher than assumed so far.

\section{Acknowledgements}

We thank Peter Lindert for his detailed comments on a first draft of this paper, and the participants of the HI-POD conference on Historical Patterns of Development and Underdevelopment in Montevideo, December 2010, and in particular Steve Broadberry, Jeffrey Williamson, Ewout Frankema, Luis Bertola, Joerg Baten and Tommy Murphy. We also are grateful to the GPIH group. Leticia Arroyo Abad acknowledges funding provided by the National Science Foundation SES0649062. 


\section{Data appendix}

The data appendix includes the details about sources and methodology with respect to prices and wages. We have collected price and wage information on six regions: Mexico (especially the Mexico City area), Peru (Lima), Colombia (Bogota), Bolivia (Potosi), Chile (Santiago) and Argentina (Buenos Aires). We provide a brief discussion of both the sources of our price and wage series as well as some methodological issues that arose during the processing of this data.

All series and the underlying estimates will be made available on the Global Prices and Income Website at University of California, Davis (http://gpih.ucdavis.edu/) and at the Historical Prices and Wages website of the International Institute for Social History (www.iisg.nl/hpw).

Prices

Most prices reflect transactions from official and private institutions. These organizations kept accounting records for transactions with merchants and suppliers. As a result, the data correspond to current consumer prices. An overview of our sources is given in Table A.1.

For Mexico we were able to find price information for a long period of time, starting from the sixteenth century until the nineteenth century. The sources are public auctions, tribute collection offices, notaries, and public granaries. For the sixteenth century we used price quotations from Borah and Cook (1958) from the Mexico City area and neighbouring regions such as Coyoacán. This price source is a mix of retail, wholesale, and auction prices of wheat, maize, meat and some utility goods. Unfortunately, no price information was available for the seventeenth century. For the eighteenth century we compiled prices from Quiroz (2005), Florescano (1986) and García Acosta (1988). In addition, we added data points from primary sources from our own research at the Mexico City Archives, collected from accounting books of several hospitals in Mexico such as Hospital Juarez, Hospital San Lázaro, Hospital San Hipólito, and Hospital de dementes.

For Peru, Macera (1992) proved to be a very useful source. Covering the entire country, this work provides data for a large number of goods and regions from 1560 to 1820 . We focused on the Lima region. Even though some gaps in the price data are present, this source gives a quite complete picture of price developments in this period. Some missing information was supplemented with price information from Gootenberg (1990).

In the case of Colombia, we used Pardo's study (1972) of prices and wages in Bogota. Despite the many gaps, it is the only data source for this country available to our knowledge. For Chile and Argentina, price data availability before the 18 th century is limited. Ramon and Larrain (1982) is the main source for Chile. A few of these prices are quoted as five-year averages. We have calculated the intervening years by linear interpolation to increase the data frequency. We worked with a variety of sources to assemble price series for Buenos Aires (Argentina). For most of the eighteenth century, we used price information from the San Pedro Telmo convent accounting books, collected by Cuesta and Conti (2007). To fill the gaps in the late 18th century, we worked with Johnson (1990). His sources are varied including hospitals, the royal army, and the local municipality. The extensive collection of prices compiled by Barba (1999) was used for the first half of the nineteenth century.

Table A.1

Price sources.

\begin{tabular}{|c|c|c|c|c|c|c|c|}
\hline Source & Time period & Wheat & Maize & Beans & Beef/meat & Utility goods & Region \\
\hline \multicolumn{8}{|l|}{ Argentina } \\
\hline Cuesta and Conti (2007) & $1700-1800$ & $\mathrm{X}$ & & & $\mathrm{X}$ & & Buenos Aires \\
\hline Johnson (1990) & $1775-1811$ & $\mathrm{X}$ & & & $X$ & & Buenos Aires \\
\hline Barba (1999) & $1810-1860$ & a & $\mathrm{X}$ & & $\mathrm{X}$ & $\mathrm{X}$ & Buenos Aires \\
\hline \multicolumn{8}{|l|}{ Bolivia } \\
\hline Tandeter and Wachtel (1990) & 1676-1681, 1720-1812 & $\mathrm{X}$ & $\mathrm{X}$ & & & $\mathrm{X}$ & Potosí \\
\hline \multicolumn{8}{|l|}{ Chile } \\
\hline Ramon and Larraín (1982) & $1659-1808$ & $\mathrm{X}$ & & $\mathrm{X}$ & $\mathrm{X}$ & $\mathrm{X}$ & Santiago de Chile \\
\hline \multicolumn{8}{|l|}{ Colombia } \\
\hline Pardo (1972) & $1635-1809$ & $\mathrm{X}$ (flour) & $\mathrm{X}$ & & $\mathrm{X}$ & $\mathrm{X}$ & Bogotá \\
\hline \multicolumn{8}{|l|}{ Mexico } \\
\hline Borah and Cook (1958) & $1531-1570$ & $\mathrm{X}$ & $\mathrm{X}$ & & $\mathrm{X}$ & $\mathrm{X}$ & México City and neighbouring regions \\
\hline Quiroz (2005) & $1701-1811$ & & & & $\mathrm{X}$ & & México City \\
\hline Florescano (1986) & $1708-1810$ & & $\mathrm{X}$ & & & & México City \\
\hline García Acosta (1988) & $1655-1798$ & $\mathrm{X}$ & $\mathrm{X}$ & $\mathrm{X}$ & & & El Bajio oriental \\
\hline Garner (1985) & $1525-1819$ & & $\mathrm{X}$ & & & & Mexico city and other places \\
\hline \multicolumn{8}{|l|}{ Peru } \\
\hline Macera (1992) & $1560-1820$ & $\mathrm{X}$ & $\mathrm{X}$ & $\mathrm{X}$ & $\mathrm{X}$ & $\mathrm{X}$ & Lima \\
\hline Gootenberg (1990) & $1800-1873$ & & $\mathrm{X}$ & $\mathrm{X}$ & $\mathrm{X}$ & $\mathrm{X}$ & Lima \\
\hline
\end{tabular}

a Flour instead of wheat. 


\section{Wage sources}

The salaries series assembled here imply the assumption of contact with Europeans. The fluidity of the labour market was conditional on a variety of royal restrictions as discussed on the main text. In general, the sources are similar to the price data. Wage information is generally more sparsely available than price information. As can be observed elsewhere, nominal wages were often rather sticky remaining invariant during relatively long periods of time. We used this fact also to interpolate between observations of nominal wages when there were gaps in the available series.

For the earlier periods, we compiled the wage stipulated by the government for forced labour. For Mexico, we used the repartimiento compensation (ca 1530-1630), in particular, the wages set for unskilled labour in the cities (Gibson, 1964: 249-251) in combination with the wages actually paid out from other sources (cf Borah and Cook, 1958 and Tandeter and Wachtel, 1990). For the late colonial period, we included data from primary sources from the Mexico City Archives from the "empleados en general" section. For Potosi (Upper Peru), we resorted to the wage set for mita work before the late 17th century, but for a few years also have information about the wages paid to free labourers (Bakewell, 1984).

As in comparable studies on prices and real wages in Europe and Asia, we only consider payments to workers in low-skill occupations. Two groups of labourers are included: unskilled construction labourers (the 'standard' also used in other studies) in Mexico, Peru (1680-1820) and Argentina, and miners in Bolivia (Potosi), Peru (1597-1603) and Chile. Despite the unskilled nature of these types of jobs, the remuneration varied due to working conditions. Because work was much harder in the mines, life expectancy was reduced and skill levels were probably higher, miners probably earned a higher wage than unskilled construction workers. We do not know how large this wage gap may have been. It should, however, not be overestimated, as the mita system used in Potosi and Peru recruited a share of the Indian rural population without much training. Hatcher (1993: 399-402) has documented that wages of English miners in the early modern period were about 50\% higher than those of unskilled construction workers in the same region. In Mexico the difference may have been higher: the few observations available in the literature wages in Zacatecas (in northern Mexico) suggest that in 1550 and 1600 nominal wages of miners were between 3 to 4 times the level of that of unskilled labourers in Mexico City (Bakewell, 1971). In the 18th century this gap had fallen by one-third however: miners earned on average 4 reales per day, construction workers in Mexico city 3 reales per day, and hacienda peons 1.5 to 2 reales (Brading, 1971: 147). These figures do not include the share in the ore that the workers received as well, implying that the total wage gap was probably as large as in the 16th century (Brading, 1971: 148).

Given the variety within unskilled occupations, it raises the question what kind of labour payment we are measuring here. The wage set by the state was probably the wage actually received by the (coerced) labourers involved in the various systems, but the marginal value of their work may have been higher. In Potosi, for example, mita workers were traded at substantial prices, indicating that such a 'surplus value' existed. We showed that wages of free labourers were often much higher than those of mita workers (Bakewell, 1984). In both cases - Mexico between 1530 and 1630 and Potosi during in particular the 17th century our wage data tend therefore to underestimate the marginal product of labour, but may have been a correct measure of the money received by the majority of workers. We will return to this issue when discussing trends in real wages.

Table A.2

Sources of wage data.

\begin{tabular}{|c|c|c|c|}
\hline Source & Time period & Occupation & Region \\
\hline \multicolumn{4}{|l|}{ Argentina } \\
\hline Johnson (1990) & $1775-1810$ & Construction workers & Buenos Aires \\
\hline Barba (1999) & $1810-1860$ & Government officials, bricklayers & Buenos Aires \\
\hline \multicolumn{4}{|l|}{ Bolivia } \\
\hline Bakewell (1984) & $1574-1716$ & Unskilled miners & Potosi \\
\hline Tandeter and Wachtel (1990) & $1716-1813$ & Unskilled miners & Potosí \\
\hline \multicolumn{4}{|l|}{ Chile } \\
\hline Carmagnani (1963) & 1690-1799 & Ore cutting and transportation & El Norte Chico \\
\hline \multicolumn{4}{|l|}{ Colombia } \\
\hline Pardo (1972) & & Unskilled labourers & Bogotá \\
\hline \multicolumn{4}{|l|}{ Mexico } \\
\hline Borah and Cook (1958) & $1531-1570$ & Construction workers & México city and neighbouring Coyoacán region \\
\hline Gibson (1964) & $1530-1800$ & Construction workers & Mexico city \\
\hline Garner (1990) & 18th century & Unskilled construction labourers (probably Indians) & Mexico city \\
\hline Quiroz (2005) & $1719-1767$ & Construction workers & México City \\
\hline \multicolumn{4}{|l|}{ Peru } \\
\hline Stern (1982) & $1597-1603$ & Mita worker & Huamanga \\
\hline Macera (1992) & $1625-1760$ & Porters & Lima \\
\hline
\end{tabular}




\section{Data processing}

To calculate the cost of the basket of goods, it was necessary to convert the historical units of the quoted prices into metric equivalents. Often these units varied between regions and over time. Early in the colonial experience, Spain mandated the use of royal uniform weights and measures. Just as in the motherland, these efforts fell short of achieving standardization. At the verge of independence, merchants still complained about the diversity of units used (Carrera Stampa, 1949). It is safe to conclude that there was no widespread metrological system in Hispanic Latin America until the adoption of the metric system well into the 19th century. Fortunately, other sources have supplied metric conversions allowing us to compare the colonial data across regions.

For example, the dry measure fanega was, according to Borah and Cook (1958), 54.52 litres in 16th century Mexico; however, Barba (1999) finds it to be 137.19 L in 19th century Argentina. If no conversion for a unit in a specific region was found, we assumed that the size of this unit was equivalent to the one in a proximate region. If no specific conversion of units was given in the price source, the conversion sheets provided by the Global Price and History Group used instead. ${ }^{21}$

Table A.3

Metric conversions of the most commonly quoted units in our sample.

\begin{tabular}{|c|c|c|c|c|c|c|c|c|c|c|}
\hline \multirow[b]{2}{*}{ Vara } & \multicolumn{2}{|l|}{ Mexico } & \multicolumn{2}{|c|}{ Peru and Colombia } & \multicolumn{2}{|l|}{ Chile } & \multicolumn{2}{|l|}{ Argentina } & \multicolumn{2}{|l|}{ Bolivia } \\
\hline & 0.84 & $\mathrm{~m}$ & 0.84 & $\mathrm{~m}$ & 0.84 & $\mathrm{~m}$ & & & 0.84 & $\mathrm{~m}$ \\
\hline Fanega (dry) & 54.52 & 1 & 54.52 & 1 & 54.52 & 1 & 137.19 & 1 & & \\
\hline Arroba (liquid) & 16.13 & 1 & & & & & & & & \\
\hline Arroba (weight) & 11.502 & $\mathrm{~kg}$ & 11.502 & $\mathrm{~kg}$ & 11.502 & $\mathrm{~kg}$ & 11.485 & $\mathrm{~kg}$ & & \\
\hline Pound /libra & 0.45354 & $\mathrm{~kg}$ & 0.45354 & $\mathrm{~kg}$ & 0.45354 & $\mathrm{~kg}$ & 0.45354 & $\mathrm{~kg}$ & & \\
\hline \multirow[t]{2}{*}{ Carga $^{a}$} & 23 & $\mathrm{~kg}$ & 45.44 & $\mathrm{~kg}$ & & & & & 45.44 & $\mathrm{~kg}$ \\
\hline & 138 & $\mathrm{~kg}$ & 138 & $\mathrm{~kg}$ & & & & & & \\
\hline quintal (dry) & & & 45.94 & $\mathrm{~kg}$ & 45.94 & $\mathrm{~kg}$ & & & 45.94 & $\mathrm{~kg}$ \\
\hline
\end{tabular}

a Several conversions of the carga were used. According to Borah and Cook (1958) a carga equaled two arrobas in sixteenth century Mexico. Other sources, relating to later centuries, indicate that a carga, when used for goods such as sand or wood, equalled to 12 arrobas, which corresponds to $138 \mathrm{~kg}$.

From a monetary perspective, although the monetary unit used throughout the period was the peso of eight reales, debasements did occur throughout the colonial period. Moreover, depending on the mint in question, the silver content varied. For converting wages from pesos and reales to silver grams, we used the yearly exchange rates compiled by Burzio (1958). In the case of Mexico we applied these rates through 1731 and used while Romano (1998) for the rest of the period.

\section{Linking price series and missing data}

One particular problem of compiling welfare ratios is that price and wage data can be quite patchy: there are several gaps in price series and gaps in the price series of one good do not always correspond to gaps in a price series of another good. Hence, sometimes the dataset is balanced, but in other years, no data for sundry items such as textiles, lamp oil, or fuel are available. To overcome this problem, we have used different estimation techniques.

- To account for changing relative prices of goods over time, we created two price index series to bridge the gap: one indexed series based on the relative price at the start of the gap and one indexed series based on the relative price at the end of the gap. A weighted average was taken of these two series, with the weight of the first price series decreasing linearly over time and the weight of the second price series increasing linearly over time. This method is used in particular for covering gaps of short periods (i.e. several years) and not for larger periods of time.

- Price movements for most imported commodities in Peru, Potosi, and Chile were very similar, although the price levels were usually distinct. The best example is the price of imported textiles, which shows the same long-term trend in all regions: a strong decline between the middle of the 17th century to the $1760 \mathrm{~s}$, followed by a modest increase afterwards. Therefore, we filled gaps in the price series of textiles in one region with prices from another region. In a similar way, we used Peruvian prices to interpolate missing price data for Potosi.

- Potatoes were an important part of the Indian diet. Only for two regions, Arequipa (Peru) and Santiago (Chile) do we have very limited price data of this crop. In Chile, potato prices (per fanega) are higher (17th century) or only marginally lower (18th century) than those of wheat (Larrain, 1990). That makes them an unattractive nutritional alternative, as their caloric content is only about one-fourth of that of wheat (data from USDA). In Peru, the relative price of the potato is much lower, about onethird to one-half of the price of the same quantity of maize. In terms of calories their price is slightly lower than that of beans. Consequently, in the case of Peru, we used beans in place of potatoes as part of the budget when the data on bean prices were available (in 1670-1687 and 1723-1767 from Brown (1990): 176-178).

- In the case of various 'small' commodities such as candles and soap, the absence of price data could not always be mended by using prices from other locations or from the same region but a related product. For those cases we have estimated stylized budgets on the basis of data for Peru (1690-1710 and 1780-1800) and Argentina (1837-1850) - periods for which we

\footnotetext{
21 See "Latin American colonial metrology", http://gpih.ucdavis.edu/Converting.htm, accessed on 24 October 2010.
} 
could establish full budgets of all items of consumption; the stylized budget are: foodstuffs 70\%, of which the staple food (maize or wheat) accounted for $40 \%$; other products: textiles: $12 \%$, soap $4 \%$, candles $3 \%$, lamp oil $4 \%$, fuel $7 \%$ (total non-food $30 \%$ ). When, for example, the price of candles was lacking, we calculated the total costs of the bare-bones basket without them, and added an extra 3\% (or in fact 3/97) to account for the missing product. In this way, gaps in the dataset could be covered.

\section{References}

\section{Argentina}

Barba, F., Aproximación al estudio de los precios y salarios en Buenos Aires desde fines del siglo XVIII hasta 1860. Series y problemas en torno al tratamiento de los mismos. La Plata: Universidad Nacional de La Plata, 1999.

Cuesta, M., and A. Conti. More Souls to Feed: The Population Impact on Prices in Late Colonial Alto Peru and Buenos Aires,, Paper presented at the All-UC Economic History Group Conference, Davis, May 2007.

Ernesto Tornquist \& Co. The economic development of the Argentine Republic in the last fifty years, Buenos Aires: Ernesto Tornquist \& Co., 1919.

Johnson, L., The Price History of Buenos Aires during the Viceregal Period, in L. Johnson and E. Tandeter (eds.), Essays on the Price History of Eighteenth-Century Latin America, Albuquerque: University of New Mexico Press, 1990, pp. 137-172.s

Bolivia

Bakewell, P.. Miners of the Red Mountain, Indian Labor in Potosi, 1545-1650, Alburquerque: University of Mexico Press, 1984.

Tandeter, E., and N. Wachtel. Prices and Agricultural Production: Potosí and Charcas in the Eighteenth Century, in L. Johnson and E. Tandeter (eds.), Essays on the Price History of Eighteenth-Century Latin America, Albuquerque: University of New Mexico Press, 1990, pp. 201-277.

Chile

Carmagnani, M., El salariado minero en Chile colonial: su desarrollo en una sociedad provincial: el Norte Chico 1690-1800, Santiago: Editorial Universitaria, 1963.

Ramon, A., and J. M. Larrain. Orígenes de la vida económica chilena, 1659-1808. Santiago de Chile: Centro de Estudios Publicos, 1982.

\section{Colombia}

Pardo, A., Geografía económica y humana de Colombia, Bogotá: Ediciones Tercer Mundo, 1972.

Mexico

Borah, W. W., and S. F. Cook. Price trends of some basic commodities in central Mexico, 1531-1570, Berkeley: University of California Press, 1958.

Florescano, E., Precios del maíz y crisis agrícolas en México. 1708-1810, México: Colegio de México, 1986.

García Acosta, V. Los precios del trigo en la historia colonial de México, México: Centro de Investigaciones y Estudios, 1988. Garner, R., Price Trends in Eighteenth-Century Mexico, The Hispanic American Historical Review 65(2) (1985) 279-325.

Garner, R., Prices and Wages in Eighteenth-Century Mexico, in L. Johnson and E. Tandeter (eds.), Essays on the Price History of Eighteenth-Century Latin America, Albuquerque: University of New Mexico Press, 1990, pp. 73-109.

Gibson, C., The Aztecs under Spanish rule; a history of the Indians of the Valley of Mexico, 1519-1810, Stanford: Stanford University Press, 1964.

Quiroz, E., Entre el lujo y la subsistencia. Mercado, abastecimiento y precios de la carne en la ciudad de México, 1750-1812, México: Colegio de México, 2005.

Peru

Gootenberg, P., Carneros y Chuno: Price Levels in Nineteenth-Century Peru, Hispanic American Historical Review 70(1) (1990) $1-56$.

Macera, P., Precios del Peru XVI-XIX Fuentes, Lima: Fondo Editorial, 1992.

Stern, S., Peru's Indian Peoples and the Challenge of Spanish Conquest: Huamanga to 1640. Madison: University of Wisconsin Press, 1982.

Conversion of monetary units

Burzio, H., El peso plata hispanoamericano, Historia, 3 (1958) 9-24.

Romano, R., Moneda, seudomonedas y circulación monetaria en las economías de México, Mexico: Fondo de Cultura Económica, 1998.

\section{References}

Acemoglu, D., Johnson, S., Robinson, J., 2001. The colonial origins of comparative development: an empirical investigation. American Economic Review 91-5, 1369-1401.

Allen, R.C., 2001. The great divergence in European wages and prices from the middle ages to the First World War. Explorations in Economic History 38 , $411-447$.

Allen, R.C., Bassino, J., Ma, D., Moll-Murata, C., van Zanden, J.L., 2011. Wages, prices, and living standards in China, 1738-1925: in comparison with Europe, Japan, and India. Economic History Review 64 (1), 8-38.

Arroyo Abad, L., 2008. Inequality in Republican Latin America: the Effects of Factor Endowments and Trade. GPIH Working Paper 9.

Assadourian, C.S., 1982. El sistema de la economía colonial: mercado interno, regiones y espacio económico. IEP, Lima.

Assadourian, C.S., 1989. La despoblación indígena en Perú y Nueva España durante el siglo XVI y la formación de la economía colonial. Historia Mexicana 38 (3), 419-453.

Assadourian, C.S., 2006. Agriculture and Land Tenure. In: Bulmer-Thomas, V., Coatsworth, J., Cortes Conde, R. (Eds.), Cambridge University Press, Cambridge. 
Bakewell, P., 1971. Silver Mining and Society in Colonial Mexico, Zacatecas 1546-1700. Cambridge University Press, Cambridge.

Bakewell, P., 1984. Miners of the Red Mountain, Indian Labor in Potosi, 1545-1650. University of Mexico Press, Alburquerque.

Barba, F., 1999. Aproximación al estudio de los precios y salarios en Buenos Aires desde fines del siglo XVIII hasta 1860. Series y problemas en torno al tratamiento de los mismos. Universidad Nacional de La Plata, La Plata.

Baten, J., Carson, S., 2010. Latin American anthropometrics, past and present - an overview. Economics and Human Biology 8, 141-144.

Bauer, A.J., 1979a. Rural workers in Spanish America: problems of peonage and oppression. Hispanic american historical review 59 (1), 34-63.

Bauer, A.J., 1979b. Expansion economica y sociedad rural : el caso chileno en el siglo XIX. Ediciones Nuestra America, Santiago.

Blanco, M., Romero Sotelo, M.E., 2000. Tres Siglos de Economía Novohispana. Mexico, UNAM.

Borah, W.W., Cook, S.F., 1958. Price trends of some basic commodities in central Mexico, 1531-1570. University of California Press, Berkeley.

Brading, D.A., 1971. Miners and Merchants in Bourbon Mexico, 1763-1810. Cambridge University Press, Cambridge.

Broadberry, S., Campbell, B., Klein, A., Overton, M., van Leeuwen, B., 2010. British Economic Growth, 1270-1870: Some Preliminary Estimates. University of Warwick.

Brown, K.W., 1990. Price Movements in Eighteenth-Century Peru: Arequipa. In: Johnson, L., Tandeter, E. (Eds.), Essays on the Price History of Eighteenth-Century Latin America. University of New Mexico Press, Albuquerque, pp. 173-201.

Burzio, H., 1958. El peso plata hispanoamericano. Historia 3, 9-24.

Carmagnani, M., 1963. El salariado minero en Chile colonial: su desarrollo en una sociedad provincial: el Norte Chico 1690-1800. Editorial Universitaria, Santiago.

Carmagnani, M., 1967. Colonial Latin American demography: growth of Chilean population, 1700-1830. Journal of Social History 1 (2), $179-191$.

Carmagnani, M., 1973. Les mécanismes de la vie économique dans une société coloniale: Le Chili (1680-1830). SEVPEN, Paris.

Carrera Stampa, M., 1949. The evolution of weights and measures in New Spain. The Hispanic American Historical Review 29 (1), 2-24.

Challú, A., 2010. The Great Decline: Biological Well-Being and Living Standards in Mexico, 1730-1840. In: Salvatore, Ricardo D., Coatsworth, John H., Challú, Amílcar E. (Eds.), Living Standards in Latin American History: Height, Welfare, and Development, 1750-2000. Harvard University Press, Cambridge, MA.

Coastworth, J., Summerhil, W., 2011. The New Economic History of Latin America: Evolution and Recent Contributions in the Oxford Handbook of Latin American History, edited by José Moya. Oxford University Press, Oxford.

Coatsworth, J.H., 1990. Economic History and the History of Prices in Colonial Latin America. In: Johnson, L., Tandeter, E. (Eds.), Essays on the Price History of Eighteenth-Century Latin America. University of New Mexico Press, Albuquerque, pp. 21-35.

Cook, S.F., Borah, W., 1979. Essays in Population History, vol. III. University of California Press, Berkeley.

Cuesta, M., Conti, A., 2007. More Souls to Feed: The Population Impact on Prices in Late Colonial Alto Peru and Buenos Aires. Paper presented at the All-UC Economic History Group Conference, Davis.

Dobyns, H.F., 1963. An outline of Andean epidemic history to 1720. Johns Hopkins University, Baltimore.

Engerman, S., Sokoloff, K., 1997. Factor Endowments, Institutions, and Differential Paths of Growth Among New World Economies. In: Haber, S. (Ed.), How Latin America Fell Behind. Stanford, Palo Alto, pp. 260-304.

Florescano, E., 1986. Precios del maíz y crisis agrícolas en México. 1708-1810. Colegio de México, México.

Furtado, C., 1976. Economic development of Latin America: historical background and contemporary problems. Cambridge University Press, Cambridge.

García Acosta, V., 1988. Los precios del trigo en la historia colonial de México. México: Centro de Investigaciones y Estudios.

Garner, R.L., 1985. Price trends in eighteenth-century Mexico. Hispanic American Historical Review 65 (2), 279-326.

Garner, R.L., 1990. Prices and wages in eighteenth-century Mexico. In: Johnson, L., Tandeter, E. (Eds.), Essays on the Price History of Eighteenth-Century Latin America. University of New Mexico Press, Albuquerque, pp. 73-109.

Gibson, C., 1964. The Aztecs under Spanish rule; a History of the Indians of the Valley of Mexico, 1519-1810. Stanford University Press, Stanford.

González, R.D., 2009. Prices and wages in Bourbon Mexico from an international comparative perspective. Paper presented at A Comparative Approach to Inequality and Development: Latin America and Europe conference, Madrid.

Gootenberg, P., 1990. Carneros y Chuno: Price Levels in Nineteenth-Century Peru. Hispanic American Historical Review 70 (1), 1-56.

Hatcher, J., 1993. The History of the British Coal Industry, I. Before 1700. Oxford University Press, Oxford.

Hidalgo, J., The Indians of Southern South America in the middle of the sixteenth century in the Cambridge History of Latin America edited by Leslie Bethell, volume $1,1984$.

Hilton, R., 1973. Bond Men made Free: Medieval Peasants Movement and the English Rising of 1381. Temple Smith, London.

Hoffman, P.T., 1996. Growth in a Traditional Society. The French Countryside 1450-1815. Princeton U.P, Princeton.

Johnson, L., 1990. The Price History of Buenos Aires during the Viceregal Period. In: Johnson, L., Tandeter, E. (Eds.), Essays on the Price History of EighteenthCentury Latin America. University of New Mexico Press, Albuquerque, pp. 137-173.

Larrain, J., 1990. Gross National Product and Prices: the Chilean case in the seventeenth and eighteenth centuries. In: Johnson, L., Tandeter, E. (Eds.), Essays on the Price History of Eighteenth-Century Latin America. University of New Mexico Press, Albuquerque, pp. 109-137.

Livi Bacci, M., 2008. Conquest: the Destruction of the American Indios. Polity Press, Cambridge.

Lockhardt, James, Schwartz, Stuart B., 1983. Early Latin America. Cambridge University Press, Cambridge.

Loveman, B., 1979. Critique of Arnold J. Bauer's “Rural workers in Spanish America: problems of peonage and oppression”. Hispanic American historical review 59 (3), $478-485$

Macera, P., 1992. Precios del Peru XVI-XIX Fuentes. Fondo Editorial, Lima.

Maddison, A., 2001. The World Economy: a Millennial Perspective. OECD, Paris.

Malvido, E., 2006. La poblacion, siglos XVI al XX. Editorial Oceano, Mexico.

McCaa, Robert, 1995. Spanish and Nahuatl Views on Smallpox and Demographic Catastrophe in Mexico. Journal of Interdisciplinary History 25 (3), $397-431$.

McCaa, Robert, 2000. The Peopling of Mexico from Origins to Revolution. In: Haines, Michael, Steckel, Richard (Eds.), The Population History of North America. Cambridge University Press, Cambridge.

Newson, L.A., 1985. Indian Population Patterns in Colonial Spanish America. Latin American Research Review 20 (3), 41-74.

Newson, L.A., 2006. The Demografic Impact of Colonization. In: Bulmer-Thomas, V., Coatsworth, J., Cortes Conde, R. (Eds.), The Cambridge Economic History of Latin America. Cambridge University Press, Cambridge.

Özmucur, S., Pamuk, Şevket, 2002. Real Wages and Standards of Living in the Ottoman Empire, 1489-1914. Journal of Economic History 62 (2), $293-321$.

Pardo, A., 1972. Geografía económica y humana de Colombia. Bogotá: Ediciones Tercer Mundo.

Persson, K.G., 1991. Agrarian productivity in medieval agriculture: Tuscany and the 'Low Countries. In: Campbell, Bruce M.S., Mark, Overton (Eds.), Land labour and livestock: historical studies in European agricultural productivity. Manchester University Press, Manchester and New York, pp. 124-143.

Prados de la Escosura, L., 2009. Lost decades? Economic Performance in post-Independence Latin America. Journal of Latin American Studies 41 (2), $279-307$.

Puente Brunke, J. de la, 1992. Encomienda y encomenderos en el Perú: estudio social y político de una institución colonial. Excma. Diputación Provincial de Sevilla, Sevilla.

Quiroz, E., 2005. Entre el lujo y la subsistencia: Mercado, abastecimiento y precios de la carne en la ciudad de México, 1750-1812. El Colegio de México, México.

Ramon, A., Larrain, J.M., 1982. Orígenes de la vida económica chilena, 1659-1808. Santiago de Chile: Centro de Estudios Publicos.

Romano, R., 1998. Moneda, seudomonedas y circulación monetaria en las economías de México. El Colegio de México, México.

Romano, R., 2004. Mecanismo y elementos del sistema económico colonial americano, siglos XVI-XVIII. Fondo de Cultural Económica, México.

Salvucci, R.J., 1987. Textiles and Capitalism in Mexico: An Economic History of the Obrajes, 1539-1840. Princeton University Press, Princeton.

Shea, Daniel E., 1992. A Defense of Small Population Estimates for the Central Andes in 1520. In: Denevan, W.M. (Ed.), The Native Population of the Americas in 1492. University of Wisconsin Press, Madison.

Simpson, L.B., 1966. The Encomienda in New Spain: the beginning of Spanish Mexico. Berkeley University Press, Berkeley.

Steinfeld, R., 1991. The Invention of Free Labor: the Employment Relation in English and American Law and Culture, 1350 - 1870. Un. Of North Carolina Press, Chapel Hill \& London.

Stern, S.J., 1982. Peru's Indian Peoples and the Challenge of Spanish Conquest: Huamanga to 1640. University of Wisconsin Press, Madison. 
Sugihara, K., 2007. The second Noel Butlin lecture: labour-intensive industrialisation in global history. Australian Economic History Review 47 (2), $121-154$. Tandeter, E., 1993. Coercion and Market, Silver Mining in Colonial Potosi, 1692-1826. University of Mexico Press, Albuquerque.

Tandeter, E., Wachtel, Nathan, 1990. Prices and Agricultural Production: Potosí and Charcas in the Eighteenth Century. In: Johnson, L., Tandeter, E. (Eds.), Essays on the Price History of Eighteenth-Century Latin America. University of New Mexico Press, Albuquerque, pp. 201-277.

Tandeter, E., Milletich, V., Otilde Ollier, M., Rubal, B., 1995. Indians in Late Colonial Markets. In: Larson, B., Harris, O., Tandeter, E. (Eds.), Sources and Numbers in Ethnicity, Markets, and Migration in the Andes: At the Crossroads Of History and Anthropology. Duke University Press, Durham.

Taylor, A.M., 1997. Peopling the Pampa: on the impact of mass migration to the river plate, 1870-1914. Explorations in Economic History 34 (68), $100-132$. Van Young, E., 1981. Hacienda and Market in Eighteenth Century Mexico. University of California Press, Berkeley.

Van Young, E., 1992. La crisis del orden colonial: estructura agraria y rebeliones populares de la Nueva España, 1750-1821. Alianza Editorial, Mexico.

van Zanden, J.L., 1999. Wages and the standard of living in Europe, 1500-1800. European Review of Economic History 3 (2), 175-198.

Van Zanden, J.L., 2009. The Long Road to the Industrial Revolution. The European Economy in a Global Perspective, 1000-1800. Brill Publishers, Leiden.

Zavala, S., 1935. La encomienda indiana. Imprenta Helenica, Madrid. 